IRSTI $29.05 .45,29.15 .35$

\author{
Shaulov S.B. ${ }^{1,2}$, Saduyev N.O. ${ }^{1,5}$, Beznosko D. ${ }^{4}$, Kalikulov O.A. ${ }^{3}$, \\ Zhukov V.V. ${ }^{1}$, Ryabov V.A. ${ }^{\text {, }}$, Shepetov A.L. ${ }^{1}$, Piskal V.V. ${ }^{1}$, \\ Muhkamejanov E.S. ${ }^{3,5}$, Shinbulatov S.K. ${ }^{3^{*}}$, Zhumabayev A.I. ${ }^{3}$, \\ Utey Sh.B. ${ }^{3,5}$, Yerezhep N.O. ${ }^{3}$
}

${ }^{1}$ P.N. Lebedev Physical Institute of the Russian Academy of Sciences, Russia, Moscow ${ }^{2}$ Moscow Institute of Physics and Technology (State University), MIPT (SU), Russia, Moscow

${ }^{3}$ Al-Farabi Kazakh National University, Kazakhstan, Almaty

${ }^{4}$ Bard Early College in New Orleans, New Orleans, LA 70117,

${ }^{5}$ National Nanotechnology Laboratory of Open Type Al-Farabi Kazakh National University, Kazakhstan, Almaty e-mail: saken_199303@mail.ru

\title{
METHOD FOR DETERMINING ANGLES IN X-RAY EMULSION CHAMBERS
}

An analysis of the measurement procedure for the zenith and azimuth angles $u$ and $\varphi$ in the X-ray emulsion chambers (XREC) of ADRON and PAMIR experiments is presented. Earlier, asymmetry was observed in distributions of azimuth angles of gamma and hadron families. A detailed analysis of methodological errors in measuring $\vartheta, \phi$ angles allowed us to establish the causes of the distortion of azimuth angles distributions. There are two reasons: systematic errors in the measurement of zenith angles by MBS-2 microscopes, used both in the PAMIR experiment, and in the ADRON experiment, and the inclination of XREC based on the subsidence. Calculations showed that the total systematic error $\Delta v \approx 4^{\circ}$ completely explains the observed azimuthal asymmetry. Formulas for correcting $\vartheta$ and $\varphi$ angles are given. The recalculation of the angles by the indicated formulas showed that this corrects the distribution of the azimuthal angles $\varphi$. The REC plane should be set relative to the horizontal with an accuracy of no worse than 1 degree in order to avoid distortion of the angular distributions.

Key words: XREC, ADRON, EAS, ionization chambers, cascades, MBS-2 microscope, Gaussian.

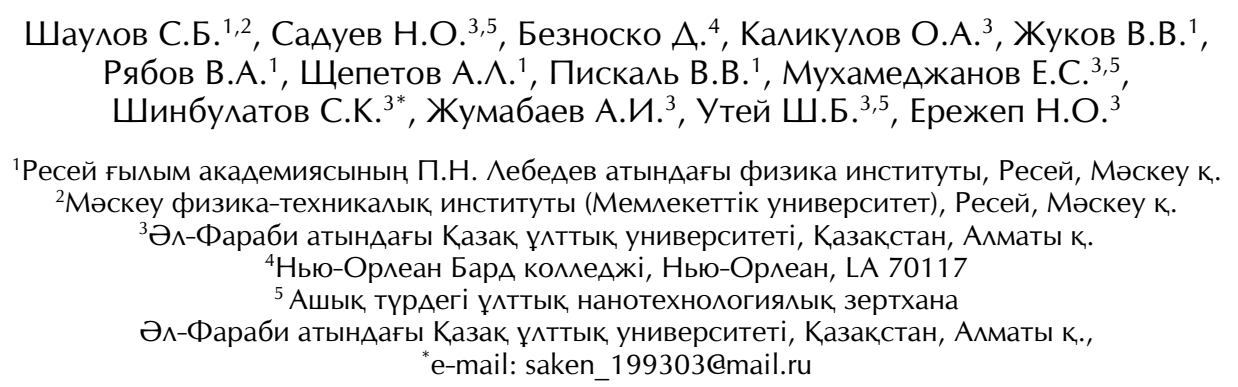

\section{Рентген эмульсия камераларында бұрыштарды анықтау әдісі}

РентгенАі эмульсия камераларында (ХРЭК) зенит және азимут бұрыштары $\mu$ және ф әдістерін ААРОН және ПАМИР эксперименттеріне та^Аау ұсыны^ды. Асимметрия гамма және аАроникалық отбасылардың азимуталды бұрыштарын бөлу кезінде байқалды. $ө$, ф бұрыштарын өлшеудегі әдіснамалық қателерді егжей-тегжейлі та^дау азимуталы бұрыштардың таралуының бұрмалану себептерін анықтауға мүмкіндік берді. Екі себеп бар: ПАМИР экспериментінде және AАPOH экспериментінде пайдаланылатын MBS-2 микроскоптарын пайдаланып зенит бұрыштарын өлшеуде жүйелі қателер және шөгінділерге негізделген ХРЭК көлбеуі. Есептеулер көрсеткендей, жүйелік қателік $\Delta v \approx 4{ }^{\circ}$ толық азимуталды асимметрияны толығымен түсіндіреАі. Формулалар түзетуге бұрыштары $\theta$ және ф. Берілген формулаларды пайдалана отырып, бұрыштарды 
қайта есептеу бұл азимуталы бұрыштарды ф бөлуін түзететіндігін көрсетті. Бұрыштық Аистрибутивтердің бұрмалануын болдырмау үшін РЭК жазықтығы кемінде 1 градус дәлдікпен горизонтальмен салыстырылуы керек.

Түйін сөздер: XREC, АAPOH, KAH, ионизациялық камералары, каскаАтар, MBS-2 микроскопы, Гаусс.

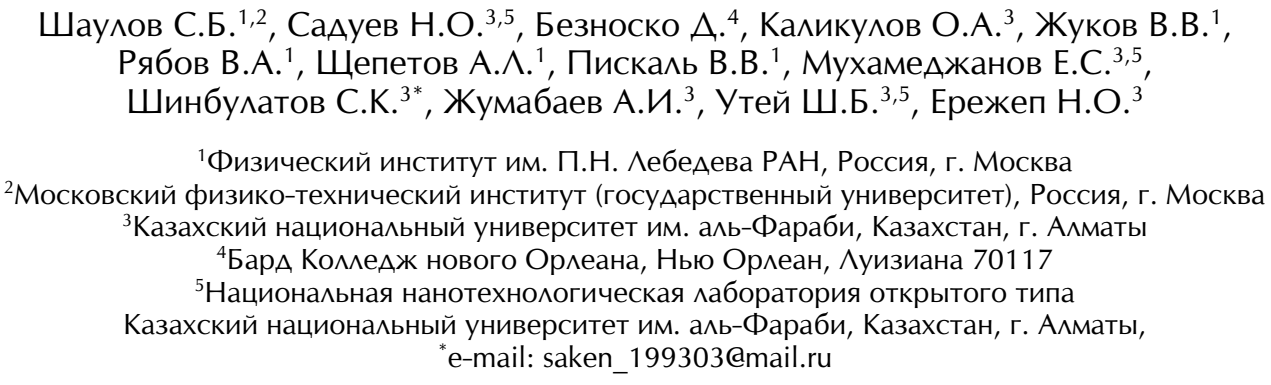

\section{Способ определения углов в рентгеновских эмумьсионных камерах}

Представлен анализ методики измерения зенитных и азимутальных углов $u$ и $\varphi$ в рентгеновских эмульсионных камерах (ХРЭК) экспериментов ААРОН и ПАМИР. Ранее асимметрия наблюдалась в распределениях азимутальных углов гамма- и аАронных семейств. Аетальный анализ методических ошибок при измерении углов $\vartheta, \varphi$ позволил установить причины искажения распределений азимутальных углов. Есть Аве причины: систематические ошибки в измерении зенитных углов с помощью микроскопов MBS-2, используемых как в эксперименте ПАМИР, так и в эксперименте ААРОН, и наклон ХРЭК, основанный на проседании. Расчеты показали, что суммарная систематическая ошибка $\Delta v \approx 4^{\circ}$ полностью объясняет наблюдаемую азимутальную асимметрию. Приведены формулы для коррекции углов $\vartheta$ и $\varphi$. Пересчет углов по указанным формулам показал, что это корректирует распределение азимутальных углов $\varphi$. П^оскость РЭК Аолжна быть установлена относительно горизонтали с точностью не ниже 1 градуса, чтобы избежать искажения угловых распределений.

Кмючевые слова: XREC, AАPOH, ША^, ионизационные камеры, каскаАы, микроскоп MBS 2, Гаусс.

\section{Introduction}

Characteristics of cosmic rays (CR) in the energy region above $19^{15} \mathrm{eV}$ are studied in groundbased experiments deep in the atmosphere. The spectrum and composition of $\mathrm{CR}$ is restored by parameters of extensive atmospheric showers (EAS) generated by CR nuclei. Of greatest interest is the small area of EAS near its axis, the EAS cores, where the most energetic hadrons are concentrated. The most informative core detector is the $\mathrm{x}$-ray emulsion chamber (XREC) [1-8]. To determine the primary energy is necessary to register the entire shower, for this purpose XREC is combined with EAS electronic detectors in the so-called hybrid installations [9-15].

The hybrid experiment ADRON [16-23] was started in 1985 to combine the techniques of the EAS and the XREC. The unification of events in the XREC with the EAS was made statistically, using information about the location and angles of the EAS and events in the XREC. Such a method particularly requires obtaining reliable information about angles in the XREC [24-28]. It is known from practice that processing of film information always contains operator errors. To reduce the number of measurement errors, the angles of events in the REC were measured twice and by different operators. With a significant discrepancy between the values of at least one of two angles, a control measurement was made. This procedure reduced the number of errors from $10 \%$ to $2 \%$ [24].

The installation of ADRON was operated at the Tien Shan station $\left(690 \mathrm{~g} / \mathrm{cm}^{2}\right)$ from 1985 to 1991 . In the experiment, two types of XRECs with an area of $162 \mathrm{~m}^{2}$ were exhibited. The designs of both types of XRECs are shown in Figure 1. In 1985-1986, two half-years and in 1986-89 three one-year exposures of the hadron chamber were made in 1989-1991, two single-year exposures of a thin lead chamber. 

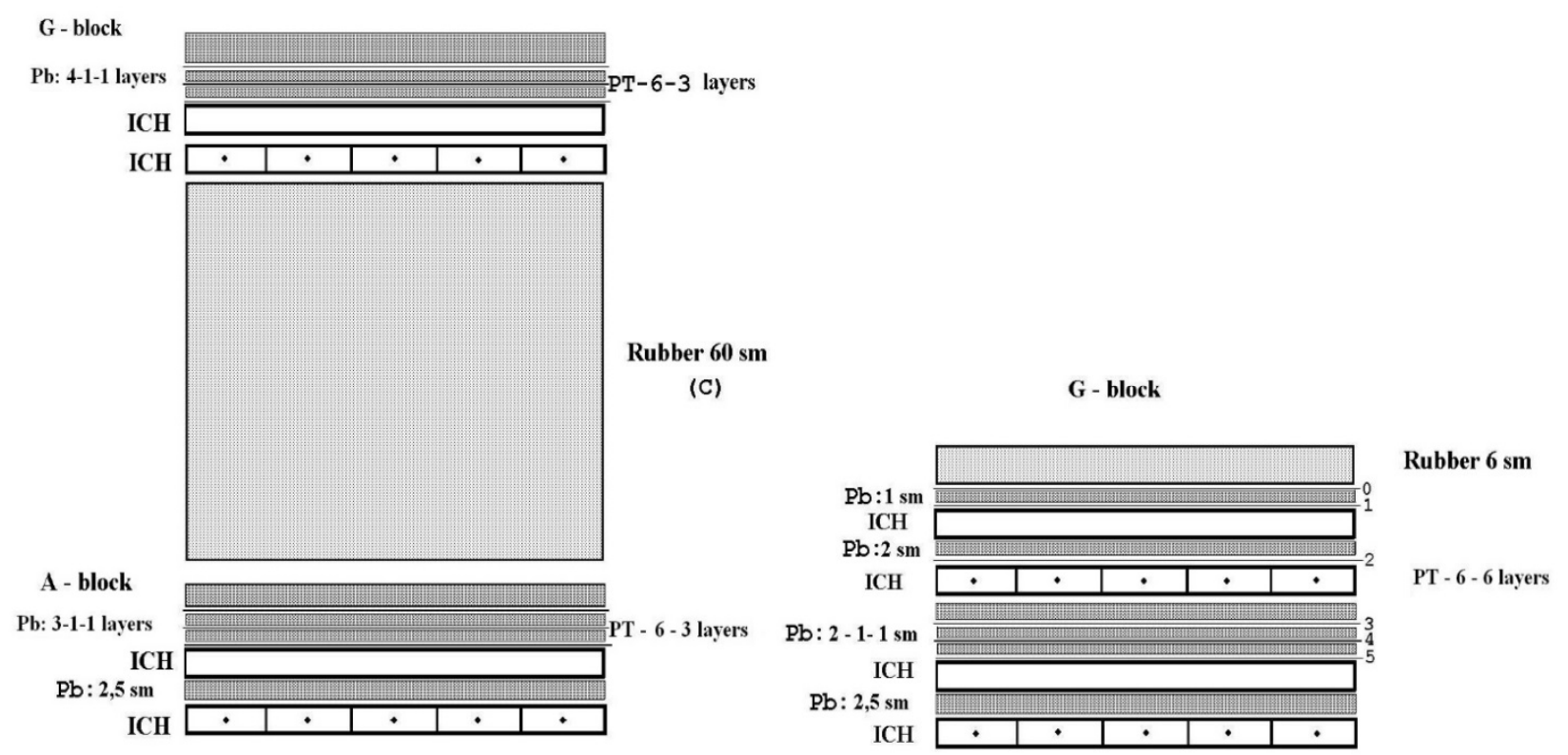

Figure 1 - X-ray emulsion chambers (XRECs) of the ADRON experiment

For comparison with EAS in the XREC, gamma-ray families with a total energy of $\sum E_{\gamma} \geq 10$ $\mathrm{TeV}$ were selected. Statistics of such events in the exposures of 1985-1989 (hadron chamber) was 2816 for the gamma-ray unit, and 2222 for the hadron block. In expositions of 1989-1991 (thin lead chamber) it was about 1004 of such events (gammafamily). Figure 2 shows the spectra of the total energy of the families $\sum E_{\gamma}$ for the $\Gamma$-block and $\sum E_{\gamma}{ }^{h}$ for the A-block of the hadron XREC [25]. In the $\Gamma$ block gamma-quanta families with energies above 2-4 TeV formed during the decay of $\pi^{0}$-mesons are detected. Charged $\pi^{ \pm}$-mesons interact in the carbon block of the XREC. In this case, the $\pi^{0}$ mesons and gamma quanta from their decay are also registered in the hadron block of the XREC. The energy of these families of gamma quanta is denoted as $\sum E_{\gamma}{ }^{h}$, where $E_{\gamma}{ }^{h}$ is the part of the charged hadron energy released into gamma quanta.

Figure 3 shows the distributions of selected events by multiplicity. The left figure shows the spectra in the $\Gamma$-block of the hadron XREC (upper spectrum) and the spectrum for a thin lead chamber (bottom). The break in the spectrum of the lead chamber is due to the presence of gaps occupied by ionization chambers. The right figure shows the multiplicity spectrum for the A-block of the hadron XREC.

Figure 4 shows the distributions of azimuth angles measured in the $\mathrm{G}$ and A-blocks of the hadron chamber (2 and 5 series, respectively) [25]. The azimuthal distributions are noticeable, at the level of $6 \sigma$, different from the uniform ones, which contradicts the data on CR at energies of the $10^{15} \mathrm{eV}$ order and higher. This means that distortions of distributions must be linked with methodological reasons. Most likely this can be due to an error in definition of the vertical. It is known that due to a sharp decrease in the intensity of cosmic rays with an angle $\theta$, the deviation from the vertical should lead to a significant non-distribution of events between different azimuthal directions. 

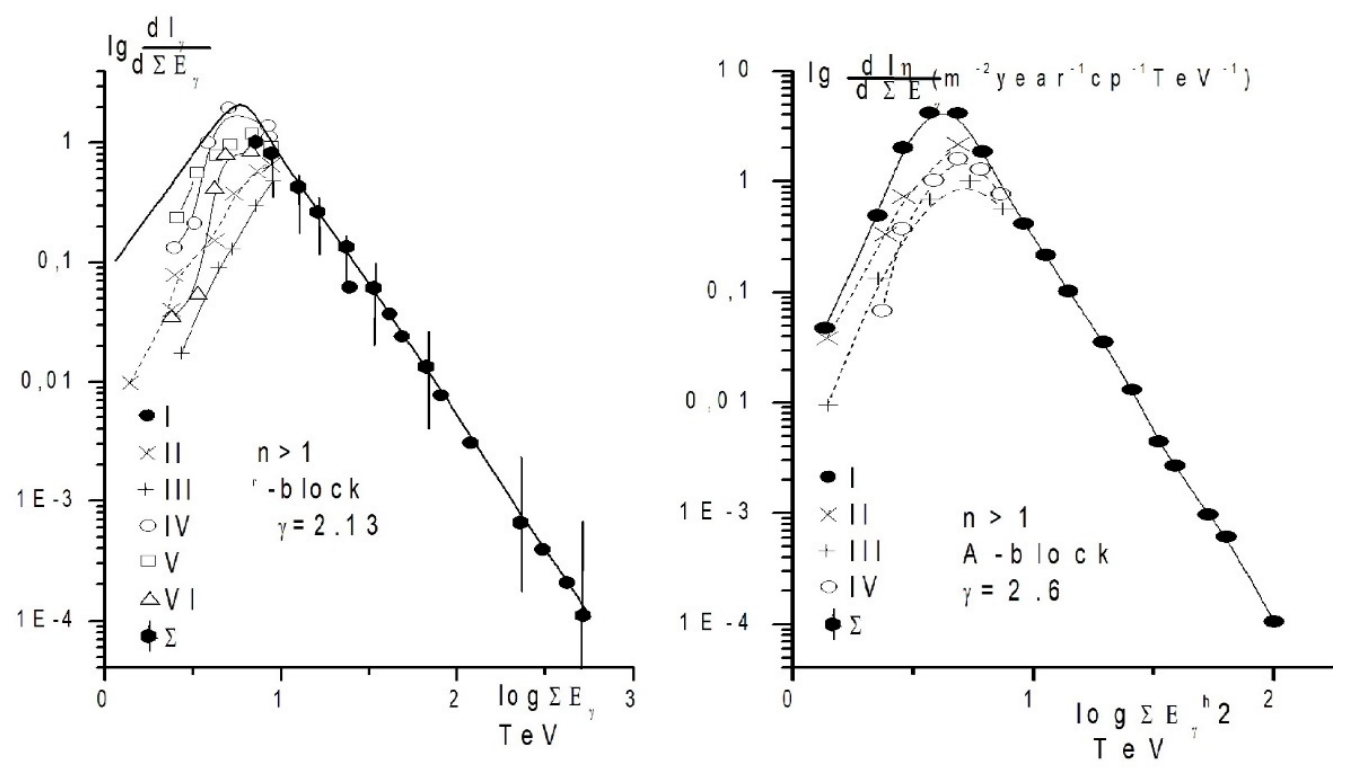

Figure 2 -The spectra of $\sum E_{\gamma}$ and $\sum E_{\gamma}{ }^{h}$ for families selected in gamma and hadron blocks at $n_{\gamma, h} \geq 1$
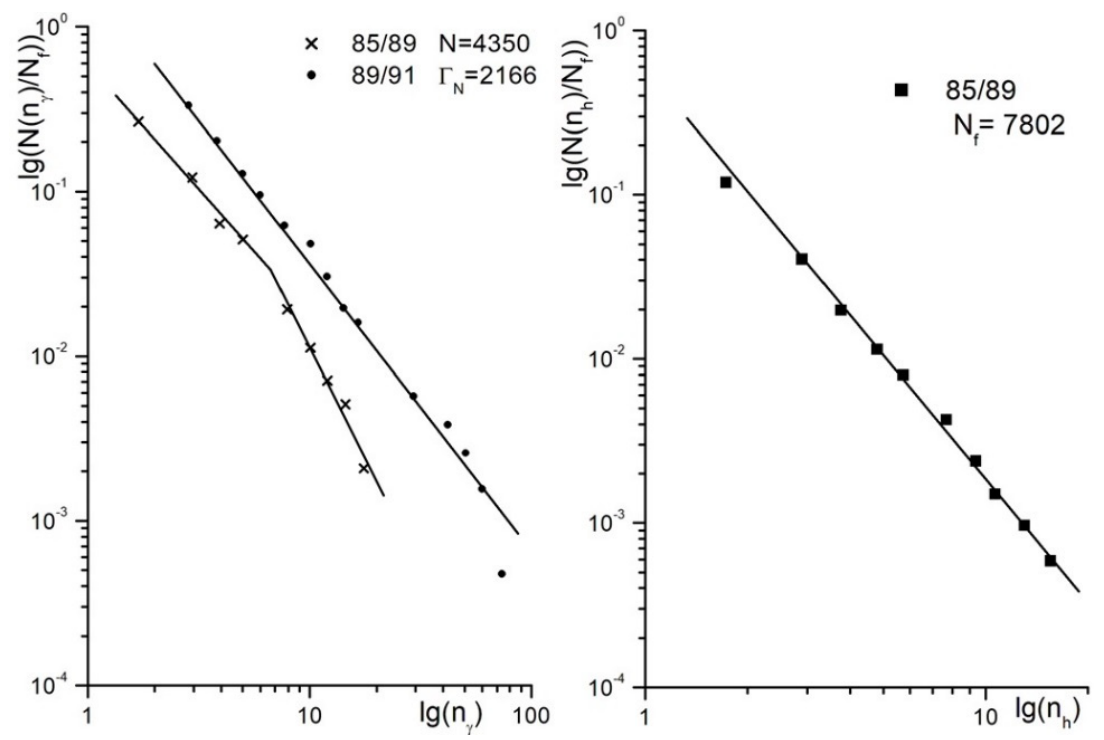

Figure 3 - Integral spectra of multiplicities in the G- and A-blocks of the XREC (without selection on the threshold).
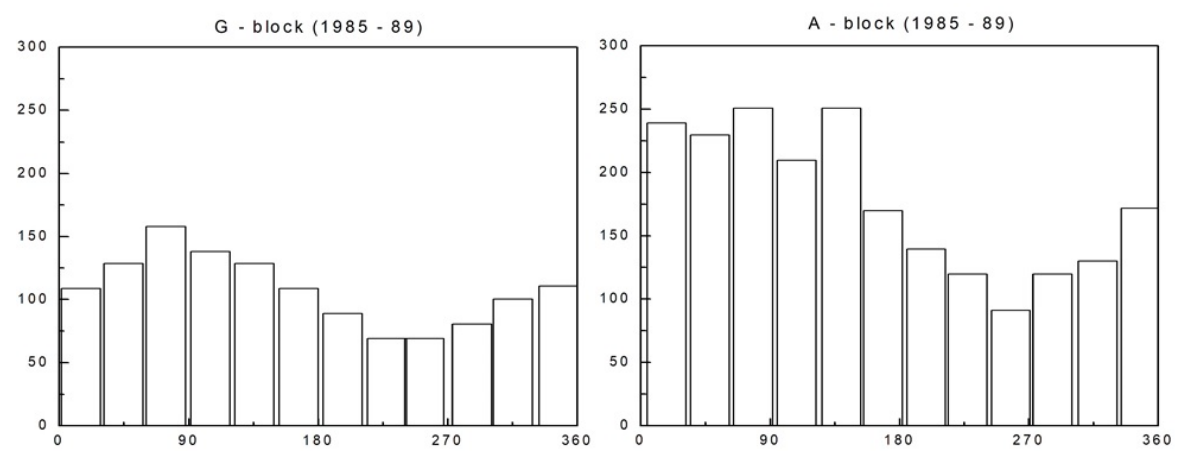

Figure 4 - Differential distributions of the azimuthal angles $\varphi$ in the G- and A-blocks of the XREC 


\section{Estimation of the distortion of azimuthal distributions}

The differential CR spectrum with respect to the number of particles $N$ at a depth $x$ in the atmosphere is written in the form [26]:

$$
\frac{d I}{d N \cdot d \theta \cdot d \varphi}=A(\theta, x) N^{-(k+1)} \sin \theta,
$$

where $k$ is the index of the spectrum of showers with respect to the number of particles.

If we do not take into account the change in the atmosphere density along shower path,

$$
A(\theta, x)=\exp \left(-\frac{k}{\Lambda}\left(\frac{x}{\cos \theta}-x\right)\right) \approx \cos ^{\frac{k}{\Lambda} x} \theta,
$$

where $\Lambda$ is the range of absorption of showers with the number of particles. Then the differential angular spectrum can be written in the form:

$$
d^{2} I=\frac{m+1}{2 \pi} I_{0} \sin \theta \cos ^{m} \theta \cdot d \theta \cdot d \varphi,
$$

where $\mathrm{I}_{0}$ is the total intensity of the events, and $\mathrm{m}=$ $k$

If this expression is integrated with respect to $v$, then we obtain:

$$
d I(\rangle \theta)=\frac{I_{0}}{2 m} \cos ^{m+1} \theta \cdot d \varphi,
$$

uniform distribution by $\varphi$.

Methodical deviation from the vertical is equivalent to rotating the coordinate system around any horizontal axis. Moreover, the redistribution of events between different intervals $\varphi$ depends to a large extent on the value of the exponent $m$, which in our case is $m=8.2$ and 9.1 for the hadron and gamma blocks, respectively.

We consider the transformation of the differential function $d^{2} I$, when the coordinate system rotates about the $\mathrm{X}$ axis by an angle $\alpha$. Since the volume element $d V=r^{2} d r d \Omega$ is an invariant of orthogonal transformations, and $r$ does not change under rotations, then $\mathrm{d} \Omega$ also remains unchanged.
The transformation of $\cos ^{m} \theta$ is more convenient to consider in Cartesian coordinates, and then return to spherical, but already in the rotated coordinate system. The rotation matrix at an angle $\alpha$ around the $x$ axis has the form:

$$
\left(\begin{array}{ccc}
1 & 0 & 0 \\
0 & \cos \alpha & -\sin \alpha \\
0 & \sin \alpha & \cos \alpha
\end{array}\right)
$$

Proceeding the corresponding transformation of the Cartesian coordinates and taking into account that $\cos \theta=z / r$, we finally obtain:

$$
\begin{gathered}
d^{2} I=\frac{m+1}{2 \pi} I_{0} \cos \theta \cos ^{m} \times \\
\times \boldsymbol{\alpha}(1-\sin \boldsymbol{\phi} \cdot \operatorname{tg} \boldsymbol{\alpha} \cdot \operatorname{tg} \boldsymbol{\theta})^{m} \sin \boldsymbol{\theta} d \boldsymbol{\theta} d \boldsymbol{\phi},
\end{gathered}
$$

Taking into account the smallness of $\alpha$ and that $\theta<45^{\circ}$, we can confine to the first two terms of the polynomial in parentheses. Integrating this expression with respect to $\theta$ within $\theta, \pi / 2$, we obtain the differential distribution of azimuthal angles in the following form:

$$
\left.\frac{d I}{d \varphi}(\rangle \theta, \alpha\right)=\frac{\cos ^{m+1} \theta}{2 \pi} I_{0}(1-A \sin \varphi),
$$

where

$$
A=\frac{m(m+1)}{\cos ^{m+1} \theta} \operatorname{tg} \alpha \int_{\vartheta}^{\pi / 2} \ln ^{2} \theta \cos ^{m-1} \theta d \theta,
$$

Taking into account that $m$ is not an integer, the integral in the expression for the coefficient $A$ must be found by numerical methods. The values of the integrals (6) over $\varphi$ in the range from 0 to $\pi$, and from $\pi$ to $2 \pi$ give the expression for the asymmetry coefficient $K$ :

$$
K=\frac{\pi+2 A}{\pi-2 A}
$$

Table 1 shows the results of calculating the values of $A$ and $K$ at the experimental values of $m=8.2$ and $m=9.1$ for the hadron and gamma XREC blocks, respectively. The last column shows the experimental values of $\mathrm{K}$. 
Table 1 - The asymmetry coefficients K

\begin{tabular}{|c|c|c|c|c|c|}
\hline $\mathrm{m}$ & $\alpha$ & $\theta$ & A & $\mathrm{k}$ & $\mathrm{K}_{\mathrm{ex}}$ \\
\hline \multirow{6}{*}{8.2} & \multirow{3}{*}{$3^{\circ}$} & $0^{\circ}$ & 0.19 & 1.28 & $1.36 \pm 0.04$ \\
\hline & & $20^{\circ}$ & 0.27 & 1.41 & $1.64 \pm 0.07$ \\
\hline & & $30^{\circ}$ & 0.35 & 1.57 & $1.78 \pm 0.11$ \\
\hline & \multirow{3}{*}{$4^{\circ}$} & $0^{\circ}$ & 0.26 & 1.39 & $1.36 \pm 0.04$ \\
\hline & & $20^{\circ}$ & 0.36 & 1.59 & $1.64 \pm 0.07$ \\
\hline & & $30^{\circ}$ & 0.46 & 1.84 & $1.78 \pm 0.11$ \\
\hline \multirow{6}{*}{9.1} & \multirow{3}{*}{$3^{\circ}$} & $0^{\circ}$ & 0.20 & 1.30 & $1.26 \pm 0.04$ \\
\hline & & $20^{\circ}$ & 0.29 & 1.45 & $1.44 \pm 0.04$ \\
\hline & & $30^{\circ}$ & 0.38 & 1.63 & $1.52 \pm 0.12$ \\
\hline & \multirow{3}{*}{$4^{\circ}$} & $0^{\circ}$ & 0.27 & 1.42 & $1.26 \pm 0.04$ \\
\hline & & $20^{\circ}$ & 0.38 & 1.65 & $1.44 \pm 0.04$ \\
\hline & & $30^{\circ}$ & 0.50 & 1.94 & $1.52 \pm 0.12$ \\
\hline
\end{tabular}

Comparison of the experimental and calculated data shows that the deviation from the vertical by an angle $\alpha=3-4^{\circ}$ explains the observed asymmetry.

\section{XREC}

The procedure for measuring angles in

The RT-6M X-ray film used in the XREC has two emulsion layers applied on both sides to a substrate with a thickness of $200 \mu \mathrm{m}$. The zenith angle $\theta$ of the cascade passage through the film is measured by the relative shift of the darkening spots in the upper and lower layers. As the center of the spot, a region with a maximum of darkening is taken. The measurement is carried out using the BSM-2 microscope, which has a linear scale for determining the distance between the spots of darkening of $\Delta$, and finding $\operatorname{tg} \theta=\Delta / d$, where $\mathrm{d}$ is the thickness of the substrate. In addition, the microscope has an angular scale along which the azimuth angle of the cascade $\varphi$ is determined. The azimuth angle is formed by the coordinate axis $\mathrm{x}$ and the straight line in the plane of the film passing through both darkening spots in the direction "towards the source". The angle $\varphi$ is measured from the $x$-axis in a counter-clockwise direction. The scheme for measuring the angles is shown in the Figure 5. In each microscope, a linear scale for determining $\Delta(\theta)$ is calibrated using an objectmicrometer. In our case, we used two microscopes with a fission rate of 11.4 and $13.7 \mu \mathrm{m}$ in the object plane with $7 \mathrm{x}$ zoom. The measurement errors for $\theta$ and $\varphi$ are obtained from the geometric relationships in the following form:

$$
\Delta \theta=K \cos ^{2} \theta, \Delta \varphi=K \operatorname{ctg} \theta,
$$

where $K=0.058$.
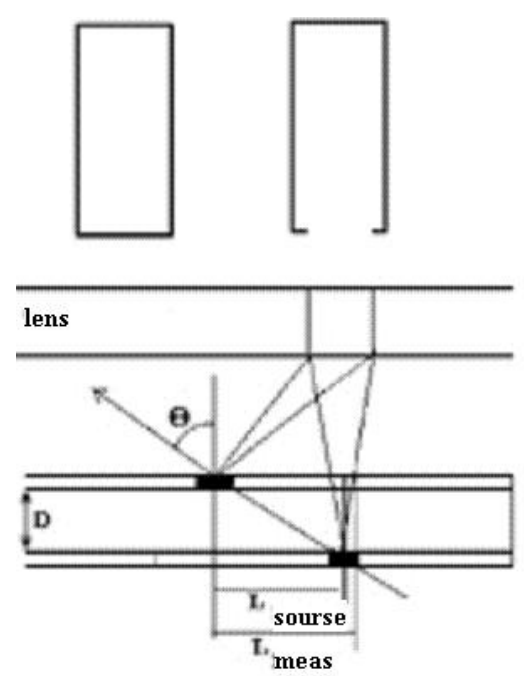

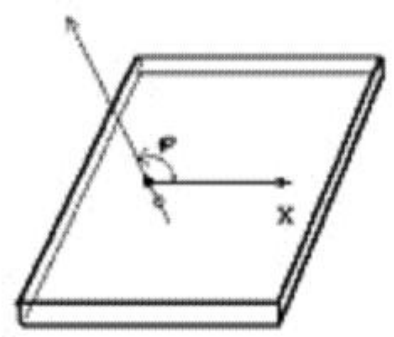

Figure 5 - Scheme of measurement of angles 
In the region of small angles $\theta$ the azimuth angle is not determined due to the overlap of the spots. The magnitude of this region depends on the diameter of the spots $D$, i.e. from the energy of the cascades. The spot diameter is related to the energy by the empirical relationship $D=35 \sqrt{ }\left(E_{\gamma}\right) \mu \mathrm{m}$, where $E_{\gamma}$ in $\mathrm{TeV}$.

The accuracy of determining the center of the spot $\Delta l \sim 0.2 D$. Then, assuming that the overlap area of the spots is $\Delta l \sim 0.5 D$, we obtain the estimate $\theta_{\text {nep }}$ $10^{\circ}$ for $E_{\gamma}=4 \mathrm{TeV}$

\section{Correction of azimuthal asymmetry}

To test the azimuthal sensitivity of the X-ray film, it was irradiated with a radioactive source of gamma quanta BIS-1M. To eliminate the azimuthal inhomogeneity of the irradiation, the film was placed on the disc of the turntable and rotated at a speed of $45 \mathrm{rpm}$. Dimensions of the darkening were made inside the rings for different angles $\varphi$. As follows from the analysis of the data, the sensitivity of the X-ray film from the azimuth angle does not depend.

It turned out that the asymmetry arises from the presence of a systematic error in determining the angle $v$ and its azimuthal dependence. The scale for determining the distance $\Delta$ between the darkening spots on the upper and lower layers of the emulsion was always located in the right eyepiece of the BSM-2 stereo microscope. The optical scheme of it is arranged in such a way that each of the eyepieces "looks" at the object table at an angle $\sim 2^{\circ}$. This is clearly seen in figure 6 , on which the laser beam passes through the optical system, reflecting from the mirror on the stage. As a result, the angle $v$ decreases for cascades coming to the right of the microscope and increases for those coming from the left. Since the orientation of X-ray films during exposure and measurement always remains this simulated azimuthal asymmetry relative to the sides of the Light.

The magnitude of the distortion of the zenith angle was determined by the difference method. For each cascade, the angle $v$ was measured at two positions of the film corresponding to the angle $\varphi=0^{\circ}$ and $180^{\circ}$. The difference between these values is $2 \alpha$. As a result of the measurements, $\alpha=2.2^{\circ} \pm 0.5^{\circ}$ was obtained for $\alpha$. This is somewhat less than the required value, which follows from the calculations. Further testing showed that the missing $2^{\circ}$ are added because of uneven subsidence under the XREC and the slope of the concrete foundation.

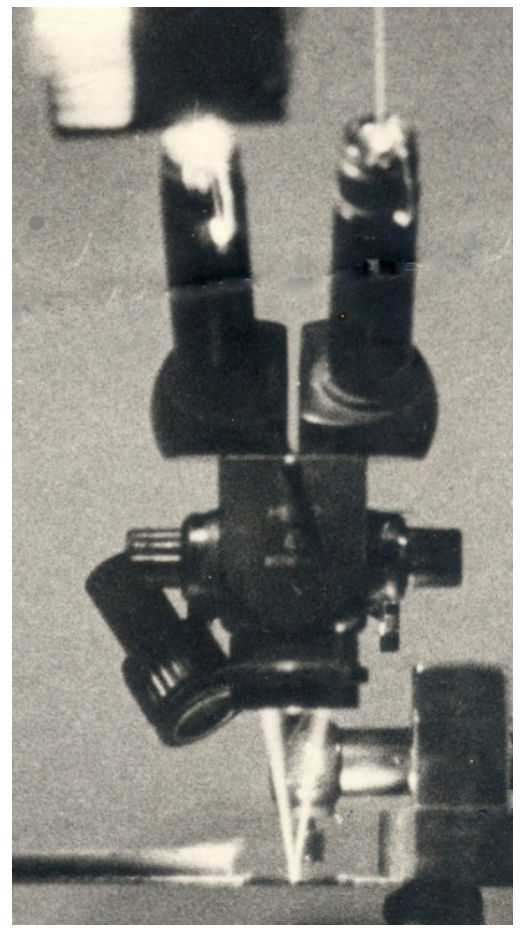

Figure 6 - Optical scheme for obtaining a stereo image in the BSM-2 microscope. The image is obtained by passing a beam of light from the laser through the microscope optics

In the Figure 7 corrected distributions of azimuth angles are given taking into account the systematic errors of the microscope and the inclination of the XREC base.

For each event in the XREC, the corrected angles were determined by the formulas (10):

$$
\begin{aligned}
& \operatorname{tg} \boldsymbol{\theta}_{\text {испр }}=\left(\operatorname{tg}^{2} \boldsymbol{\theta}^{u 3, \mu}+\operatorname{tg}^{2} \boldsymbol{\alpha}+2 \operatorname{tg} \boldsymbol{\theta}^{u 3 u} \cdot \operatorname{tg} \boldsymbol{\alpha} \cdot \cos \boldsymbol{\phi}^{u 3.4}\right)^{\frac{1}{2}}, \\
& \cos \phi_{\text {испр }}=\operatorname{tg}^{-1} \boldsymbol{\theta}_{\text {испр }}\left(\cos \boldsymbol{\phi}^{u 3 u} \cdot \operatorname{tg} \boldsymbol{\theta}^{u 3 u}+\operatorname{tg} \boldsymbol{\alpha}\right),
\end{aligned}
$$

where $\alpha$ - is the total systematic error in the zenith angle $\theta$. 


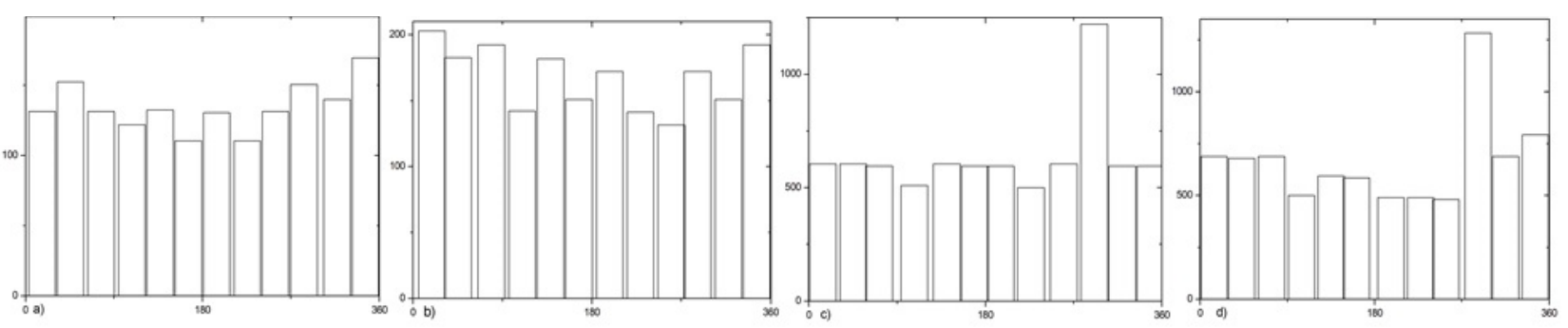

c) and d) are the same $-\theta>30^{\circ}$, but for $\theta>3^{\circ}$

Figure 7 - Differential distributions of the azimuthal angles $\varphi$ in the G- and A-blocks of the XREC

Determination of random errors in measuring the angles $\theta$ and $\varphi$

To obtain measurement errors 600 cascades were selected in the XREC HADRON and the values of their angles $v$ and $\varphi$ were measured on four different microscope BSM-2. The Figure 8 shows the distributions of measurement errors $\Delta \theta, \Delta \varphi$, obtained by subtracting individual measurements from the average of four dimensions.

The distributions are practically Gaussian. The gross measurement errors making up $\theta 4 \%$ and $\varphi$ $9 \%$, were detected and eliminated during the twodimensional measurement of angles. For measurement errors, the values $\Delta \theta=-0.1 .6 \pm 2.6$ are obtained for zenith and $\Delta \varphi=-0.1 \pm 8.6$ for the azimuth angles.
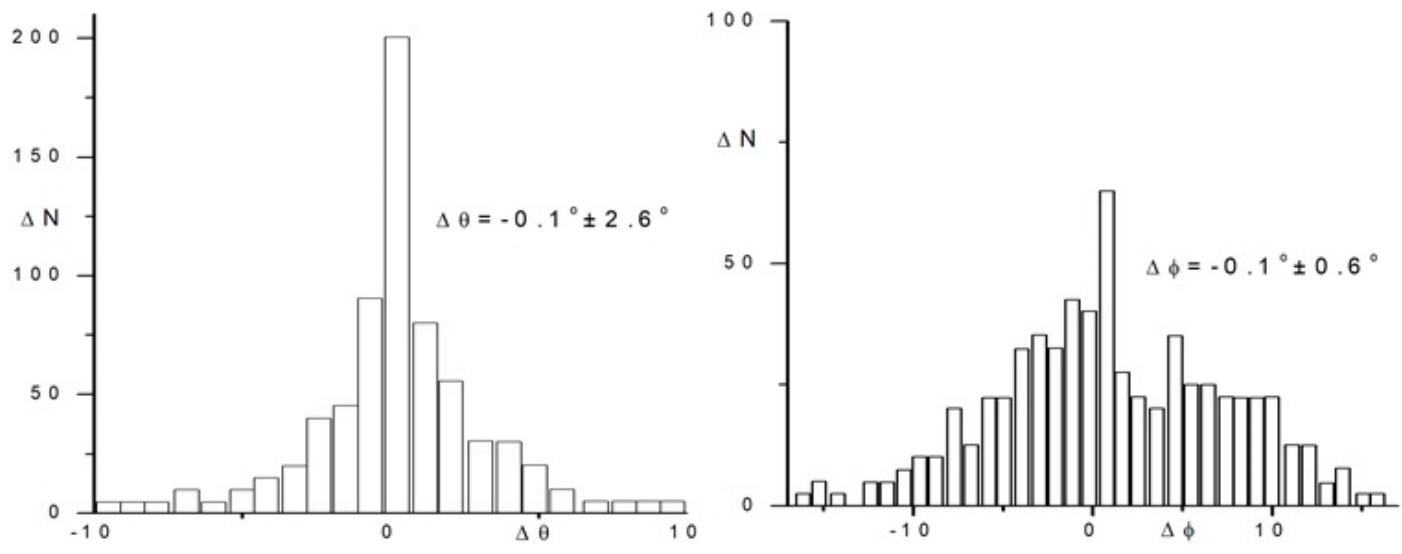

Figure 8 - Distributions of measurement errors for zenith (a) and azimuth (b) angles

\section{Conclusion}

Summarizing the results we can conclude:

The method of measuring the angles $\theta$ and $\varphi$ in the XREC with the help of stereomicroscopes BSM2 introduces a number of distortions:

1. In the range of angles $\theta=0-10^{\circ}$, the method does not work due to overlapping of the darkening heels.

2. The stereo effect in BSM-2 microscopes leads to a systematic distortion of the angles $\Delta \theta \approx 2^{\circ}$.
In order to obtain undistorted angular distributions, the XREC plane should be exposed with respect to the horizontal with an accuracy not worse than $1^{\circ}$.

\section{Acknowledgments}

This work was supported by the IRN program \#BR05236494" Fundamental and applied studies in related fields of physics of terrestrial, near-earth and atmospheric processes and their practical application". 


\section{References}

1 Baiburina S.G, Shaulov S.B.et al, Investigation Of Characteristics Of Hadron And Gamma-Ray Families With Multilayer Emulsion Chambers // 16th Intern. Cosmic Ray Conf. -1979. - Vol. 7. - P. 240-245.

2 Pamir Collaboration. The types of Emulsion Chambers in the Experiment "Pamir". Naukowe Uniwersytetu Lozkiego // LODZ - 1977. - Vol. 11. - P. 7-22.

3 Baiburina S.G., Shaulov S.B.et al, Energy Spectrum And Path For Interaction For Hadron With Energy Of 10Tev-100Tev // 16th Intern. Cosmic Ray Conf. - 1979. - Vol. 7. - P. 74-79.

4 Жданов Г.Б., Славатинский С.А., Смородин Ю.А., Зелевинская Н.Г., Пучков В.С., Денисова В.Г., Чердынцева К.В., Дунаевский А.М., Урысон А.В., Байбурина С.Г., Гусева 3.М., Шова Ш., Шу Ш. Исследование адронной составляющей космических лучей на уровне гор с помощью многослойных рентгеновских эмульсионных камер (Эксперимент «Памир») // Известия АН СССР. Физическая серия. - 1980. - Т. 44(3). - С. 457-460.

5 Жданов Г.Б., Славатинский С.А., Смородин Ю.А., Максименко В.М., Зелевинская Н.Г., Пучков В.С., Дубровина С.А., Денисова В.Г., Каневская Е.А., Чердынцева К.В., Дунаевский А.М., Урысон А.В., Байбурина С.Г., Гусева 3.М., Шаулов С.Б., Смирнова, Сминова С., Пашков А.Т. Пространственные характеристики семейств гамма-квантов (эксперимент Памира) // Известия АН СССР. Физическая серия. - 1980. - Т. 44(3). - С. 454-456.

6 Pamir Collaboration. Hadron families and intensity of primary protons at energy $1015 \mathrm{ev} / /$ Lodzinsky Working meeting. 1980. - Vol. 11. - P. 137-141.

7 Pamir Collaboration. The azimuthal structure of gamma families in the Pamir ex-periment// Proc 17-th Inter.Conf. on Cosmic Rays. - 1981. - Vol. 11. - P. 156-158

8 Памирское Коллобарация. Исследование ядерных взаимодействий в области энергий 1014-1017 эВ методом рентгеновских эмульсионных камер в космических лучах// Труды ФИАН. - 1984. - Т. 154. - С. 3-141

9 Данилова В., Шаулов С.Б. и др., Проект эксперимента по изучению адронных взаимодействий в диапазоне энергий 103-105 ТэВ (эксперимент АНИ) // Известия АН Арм.ССР. Физика. - 1982. - Т. 17(3). - С. 129-232.

10 Азарян М.О., Шаулов С. Ш., Проект установки «ШАГ» для совместной регистрации EAS и гамма-семейств // Препринт ФИАН. - 1982. - Т. 44. - С. 1-31.

11 Danilova T.V.,.Dunaevsky A.D, Shaulov S.B.et.all. The project of the experiment on investigation of hadron sand nuclei in the energy range 103-105TeV // Proc 18-th Inter. Conf. on Cosmic Rays. - 1983. - Vol. 5. - P. 520-523.

12 Danilova T.V., Dunaevsky A.D., Shaulov S.B.. The ANI installation for the study of the interaction of hadrons and nuclei in the energy range 103-105TeV // Proc 18-th Inter. Conf. on Cosmic Rays. - 1984. - Vol. 5. - P. 527-530

13 Жданов Г.Б., Славатинский С.А., Максименко В.М., Данилова Т.В., Вавилов Ю.Н., Яковлев В.И., Нестерова Н.М., Пучков В.С., Денисова В.Г., Каневская Е.А., Павлюченко В.П., Чердынцева К.В., Гусева 3.М., Шаулов С.Б., Чубенко А.П., Бейсембаев Пейсемба Вильданова Л.И., Борисов А.С., Карпова С.А., Антонова В.П., Щепетов А.Л., Аушев В.М., Бейл П.А., Гудкова Е.Н. Проект модернизации объектов Памира и Адрона для комплексного изучения EAS // Препринт ФИАН. - 1996. - T. 59. - C. 1-26.

14 Shaulov S.B., Martirosov R.M., Mamidjanian E.A., Jones L.W., Saavedra O., Tamada M., Partial reanimation of experimental complex ANI at Mt. Aragats (proposal) // Proc. of the ICRW “Aragats 2007”. - 2007. - P. 153-156.

15 Шаулов С.Б. Гипотеза о странной кварковой материи в космических лучах // Препринт ФИАН. - 2012. - Т. 19. C.3-42.

16 Shaulov S.B. // VANT ser. tech. - 1986. - Iss. ZS29 E. - 72 p.

17 Абдрашитов Д., Адамов С. и др. // Известия АН СССР. Физическая серия. - 1986. -Vol. 50 (11). - Р. $2203-2207$.

18 Adamov D.S. et al. //20 ICRC - Moscow. - 1987. - Vol. 6. - 144 p.

19 Adamov D.S. et al. // 6th ISVHECRI. - Tarbe. $-1990 .-284$ p.

20 Shaulov S.B., Statistical criteria for the combination events in EXC and EAS (Exp."Hadron") // Preprint FIAN. - 1987. Vol.245. - P. 3-12.

21 Арабкин В.В., Адамов Д.С., Шаулов С.Б. и др. К вопросу о применимости функций NCG для описания пространственного распределения электронов ШАЛ на уровне гор //Мат. Всесоюзного конф. по космическим лучам. -1989. - T.2. - C. 40-41.

22 Adamov D.S, Arabkin V.V., Shaulov S.B.et al. Phenomenological characteristics of EAS with Ne $=2105-2107$ obtained by the modern Tien-Shan installation "Hadron"// Proc 20-th Inter.Conf. on Cosmic Rays. - 1987. - Vol.5. - P. 460-463.

23 Адамов Д.С., Арабкин В.В., Вильданова Л.И., Шаулов С.Б.и др. Установка «Адрон-2» для изучения характеристик электронно-фотонной составляющей ШАЛ-стволов в диапазоне энергий 0,1-100 ПэВ // Известия АН СССР. Физическая серия. - 1991. - Т. 56(4). - С. 703-708.

24 Жансеитова 3., Сухов Л.В., Шаулов С.Б. и др. Анализ угловых распределений событий, зарегистрированных в рентгеновской эмульсионной камере адронного эксперимента //Препринт ФИАН. - 1991. - Т. 147. - С. 2-14

25 Cherdyntseva K.V., Janseitova J.K., Shaulov S.B. et al. Azimuth Asymmetry of the $\gamma$-ray, Hadron and their families flow and the analysis of the zenith angles distributions for X-ray emulsion chambers (Experiment "Hadron") // Proc 23-th Inter.Conf. on Cosmic Rays. - 1993. - Vol. 4. - P. 88-91.

26 Жансеитова 3., Сухов Л.В., Шаулов С.Б. и др. Анализ угловых распределений событий, зарегистрированных в рентгеновской эмульсионной камере адронного эксперимента // Препринт ФИАН. - 1991. - Т. 147. - С. 2-14.

27 Шаулов С.Б., Методы определения характеристик ШАЛ в комбинированных событиях и нарушения масштабирования // Препринт ФИАН. - 1996. - Т. 60. - С. 1-37.

28 Жансеитова Ж.К., Чердынцева К.В., Шаулов С.Б.. Исследование угловых спектров гамма- и адронных семейств в эксперименте Космические лучи «Адрон» (проект АДРОН-М) // Препринт ФИАН. - 1999. - Т. 32. - С .160-165. 


\section{References}

1 S.G. Baiburina, S.B. Shaulov et al, 16th Intern. Cosmic Ray Conf., 7, 240-245 (1979).

2 Pamir Collaboration, LODZ 60(11), 7-22 (1977).

3 S.G. Baiburina, S.B. Shaulov, 16th Intern. Cosmic Ray Conf. 7, 74-79 (1979).

4 G.B. Zhdanov, S.A. Slavatinsky, et al, Izvestiya AN SSSR. Fizicheskaya seriya, 44, 457-460 (1980). (in Russ).

5 G.B. Zhdanov, S.A. Slavatinsky et al., Izvestiya AN SSSR. Fizicheskaya seriya, 44(3), 454-456 (1980). (in Russ).

6 Pamir Collaboration, Lodzinsk work meeting, 11, 137-141 (1980).

7 Pamir Collaboration, ICCR 17(11), 156-158 (1981).

8 Pamir Collaboration, FIAN Proceedings, 154, 3-141 (1984). (in Russ).

9 V. Danilova, S.Sh. Shaulov, et al., Izvestiya AN Arm.SSR. Fizika, 17(3-4-4), 129 -232 (1982). (in Russ).

10 M.O. Azaryan, S.Sh. Shaulov, Preprint FIAN, 44, 1-31 (1982). (in Russ)

11 T.V. Danilova, A.D. Dunaevsky, and S.B. Shaulov, et.al. Proc 18-th Inter. Conf. on Cosmic Rays. 5, 520-523 (1983).

12 T.V. Danilova, A.D. Dunaevsky, and S.B. Shaulov, Proc 18-th Inter. Conf. on Cosmic Rays. 5, 527-530 (1984).

13 G.B. Zhdanov, S.A. Slavatinsky, et al., Preprint FIAN, 59, 1-26 (1996) (in Russ)

14 S.B. Shaulov, R.M. Martirosov, et al., ICRW “Aragats-2007”, 153-156 (2007).

15 S.B. Shaulov, Preprint of FIAN, 19 (2012). (in Russ).

16 S.B. Shaulov, VANT ser. tech., 729 (1986)

17 S.O. Abdrashitov, D.S. Adamov et al., Izvestiya AN SSSR. Fizicheskaya seriya, 50(11) 2203-2207 (1986) (in Russ)

18 D.S. Adamov et al. ICRC 20(6), 144 (1987).

19 D.S. Adamov et al. ISVHECR 6, 284 (1990).

20 S.B. Shaulov, Preprint FIAN, 245, 3-12 (1987).

21 V.V. Arabkin, D.S. Adamov, S.B. Shaulov, et al. Materials All-Union Conf. by space rays, 2, 40-41 (1989). (in Russ).

22 D.S. Adamov, V.V. Arabkin, S.B. Shaulov, et al., ICCR 20, 5, 460-463 (1987).

23 D.S. Adamov, V.V. Arabkin, L.I. Vildanova, and S.B. Shaulov, Izvestiya AN SSSR. Fizicheskaya seriya, 56(4), 703-708 (1991). (in Russ)

24 Z. Zhanseitova, L.V. Sukhov, S.B. Shaulov, et al., Preprint FIAN, 147, 2-14 (1991). (in Russ)

25 K.V. Cherdyntseva, J.K. Janseitova, S.B. Shaulov, et al., ICCR 23, 88-91 (1993).

26 J.K. Zhanseitova, K.V. Cherdyntseva, S.B. Shaulov, Preprint FIAN, 25, ,2-36 (1994). (in Russ)

27 S.B. Shaulov, Preprint LPI, 60, 1996, 1-37. (in Russ)

28 Zh.K. Zhanseitova, K.V. Cherdyntseva, and S.B.Shaulov, Preprint FIAN, 32, 160-165 (1999). (in Russ) 